\title{
Rituximab combined with liposomal doxorubicin (R-Dox) in HIV-infected patients with severe Kaposi sarcoma-associated herpes virus (KSHV) associated multicentric Castleman disease (MCD)
}

\author{
Thomas Uldrick ${ }^{1 *}$, Mark Polizzotto $^{1}$, Deirdre O'Mahony ${ }^{1}$, Karen Aleman $^{1}$, Kathy Wyvill ${ }^{1}$, Seth M Steinberg ${ }^{2}$, \\ Stefania Pittaluga ${ }^{3}$, Vickie Marshall ${ }^{5}$, Denise Whitby ${ }^{5}$, Giovanna Tosato ${ }^{4}$, Richard F Little ${ }^{1}$, Robert Yarchoan ${ }^{1}$ \\ From $12^{\text {th }}$ International Conference on Malignancies in AIDS and Other Acquired Immunodeficiencies \\ (ICMAOI)
}

Bethesda, MD, USA. 26-27 April, 2010

\section{Background}

MCD is characterized by inflammatory symptoms, splenomegaly, adenopathy, hypoalbuminemia, hyponatremia, and cytopenias. MCD in HIV-infected patients is generally KSHV-associated. No standard therapy exists. Rituximab has activity, but monotherapy may be insufficient in severe disease and can be associated with worsening of Kaposi's sarcoma (KS).

\section{Methods}

Patients with symptomatic MCD received rituximab $375 \mathrm{mg} / \mathrm{m}^{2}$ plus liposomal doxorubicin $20 \mathrm{mg} / \mathrm{m}^{2}$ every 21 days until substantial clinical improvement or disease progression. This regimen is being evaluated prospectively within an MCD natural history protocol. Additional therapy, employing agents with antiviral activity (discussed below), was generally employed to consolidate or maintain responses. Clinical, biochemical, and radiographic responses were evaluated using protocol-defined criteria. Overall complete response $(\mathrm{CR})$ required normalization of all MCD-related abnormalities.

\section{Results}

Patient characteristics: 12 (1 woman, 11 men) patients completed R-dox. Median age, 43 (34-55); median number of prior therapies 2 (0-8). Diffuse adenopathy (12); median spleen $(\mathrm{cm}), 18.5$ (12.5-28). Concurrent KS (5).

\footnotetext{
*Correspondence: uldrickts@mail.nih.gov

${ }^{1}$ HIV and AIDS Malignancy Branch, Center for Cancer Research, National

Cancer Institute, Bethesda, MD, USA

Full list of author information is available at the end of the article
}

All were receiving concurrent combination antiretroviral therapy. Baseline laboratory values, median (range): CD4 cells/ $\mu \mathrm{L}, 291$ (21-1598); C-reactive protein (mg/dL), 9.9 (0.4-21); albumin (mg/dL), 2.7 (1.5-3.3); sodium (mEq/ L), 133 (126-136); platelets $(\mathrm{K} / \mu \mathrm{L}), 70$ (10-377); hemoglobin $(\mathrm{gm} / \mathrm{dL}), 9.4(6.8-12.2)$. Median cycles received 4.5 (3-9) (Table 1)

With 9 patients receiving additional therapy after R-dox; IFNa (6), high-dose zidovudine + valganciclovir (2), additional liposomal doxorubicin (1); 6 additional patients achieved overall CR (total 75\%). KS responded in $4 / 5$ (80\%). With 31.4 months median potential followup (actual 5.5+ to 47+), estimated 2-year progression-free survival and overall survival are $61.1 \%$ and $78.6 \%$, respectively. 8/12 (67\%) remain symptom free, while 3 had recurrent MCD flares (months 7, 10, 17) responding to additional R-Dox. One had progressive MCD and worsening KS during cycle 6 and died at month 6 . At autopsy, primary effusion lymphoma was discovered. One patient died at month 17 of sepsis unrelated to therapy. Select toxicities: 9 infusion reactions (Gr. $1=3$, Gr. $2=4$, Gr. $3=2$ ) with the first dose

Table 1 Best response with R-Dox

\begin{tabular}{llll}
\hline $\begin{array}{l}\text { Response } \\
\text { Category }\end{array}$ & $\begin{array}{l}\text { Complete } \\
\text { Response }\end{array}$ & $\begin{array}{l}\text { Partial } \\
\text { Response }\end{array}$ & $\begin{array}{l}\text { Stable } \\
\text { Disease }\end{array}$ \\
\hline Clinical & $12(100 \%)$ & - & - \\
Biochemical & $10(83 \%)$ & $1(8 \%)$ & $1(8 \%)$ \\
Radiographic & $6(50 \%)$ & $6(50 \%)$ & - \\
Overall & $3(25 \%)$ & $6(50 \%)$ & $3(25 \%)$ \\
\hline
\end{tabular}


of rituximab; $6 / 60$ cycles complicated by neutropenia (Gr. $2=5$, Gr. $3=1$ ), no infectious complications.

\section{Conclusions}

$\mathrm{R}$-Dox is effective in treating severe KSHV-MCD or MCD with concurrent severe KS. Evaluation of R-Dox in KSHV-MCD is ongoing.

\section{Acknowledgements}

This article has been published as part of Infectious Agents and Cancer Volume 5 Supplement 1, 2010: Proceedings of the $12^{\text {th }}$ International Conference on Malignancies in AIDS and Other Acquired Immunodeficiencies (ICMAOI). The full contents of the supplement are available online at http://www.biomedcentral.com/1750-9378/5?issue=S1.

\section{Author details}

'HIV and AIDS Malignancy Branch, Center for Cancer Research, National Cancer Institute, Bethesda, MD, USA. ${ }^{2}$ Biostatistics and Data Management Section, Center for Cancer Research, National Cancer Institute, Bethesda, MD, USA. ${ }^{3}$ Laboratory of Pathology, Center for Cancer Research, National Cancer Institute, Bethesda, MD, USA. " Laboratory of Cellular Oncology, Center for Cancer Research, National Cancer Institute, Bethesda, MD, USA. ${ }^{5}$ Viral Oncology Section, AIDS and Cancer Virus Program, National Cancer Institute, Bethesda, MD, USA.

Published: 11 October 2010

doi:10.1186/1750-9378-5-S1-A72

Cite this article as: Uldrick et al:: Rituximab combined with liposomal doxorubicin (R-Dox) in HIV-infected patients with severe Kaposi sarcoma-associated herpes virus (KSHV) associated multicentric Castleman disease (MCD). Infectious Agents and Cancer 20105 (Suppl 1):A72.

\section{Submit your next manuscript to BioMed Central} and take full advantage of:

- Convenient online submission

- Thorough peer review

- No space constraints or color figure charges

- Immediate publication on acceptance

- Inclusion in PubMed, CAS, Scopus and Google Scholar

- Research which is freely available for redistribution

Submit your manuscript at www.biomedcentral.com/submit 